\title{
TUGAS TAMBAHAN PERAWAT DI BANGSAL PERAWATAN SEBAGAI PENGELOLA KEUANGAN; STUDI KUALITATIF
}

\section{Extra task of Nurse at the Ward as financial administrator; a qualitative study}

\author{
Bambang Wiseno $^{1 *}$, Luluk Susiloningtyas ${ }^{2,}$ Aris Dwi Cahyono ${ }^{3}$ \\ 1,2,3 Stikes Pamenang Kediri, \\ * bambangwiseno0601@gmail.com, bambangwiseno72@yahoo.com
}

\begin{abstract}
Abstrak
Rumah sakit merupakan tempat untuk pelayanan kesehatan secara umum, namun juga termasuk pelayanan lainnya yang bisa memberi kepuasan semua pengguna rumah sakit. Karyawan rumah sakit sebagai pemberi layanan juga harus mendapatkan kepuasan dalam kegiatannya. Perawat selama ini tidak hanya memberi tindakan asuhan keperawatan pada pasien namun juga pelayanan lain salah satunya yaitu administrasi keuangan ruangan.

Perawat dalam perannya di layanan kesehatan bisa sebagai advocator, educator, colaborator, coordinator, conselor dan sebagai pembaharu, dan ada tempat layanan kesehatan yang mengharuskan perawat menyelesaikan administrasi keuangan selama pasien dirawat di ruang tersebut. Pelaksanaan administrasi keuangan tidaklah mudah kecuali oleh tenaga profesional yang telah mendapatkan pendidikan khusus tentang administrasi keuangan dan hal tersebut menjadi beban tersendiri bagi perawat. Tujuan dari penelitian kualitatif ini yaitu untuk mengungkap respon perawat atas tugas administrasi keuangan di ruang perawatan. Wawancara secara mendalam terhadap perawat di rumah sakit untuk mendapatkan data tentang pengalamannya dalam mengelola administrasi keuangan. Setelah melalui analisa data dan diskusi dengan beberapa peneliti kualitatif serta klarifikasi dengan beberapa perawat didapatkan sebanyak 6 (enam) tema, yaitu; menyatakan tidak mempunyai dasar ilmu keadministrasian, merasa bertanggungjawab atas tugas-tugas diruangan termasuk administrasi keuangan, merasa bertanggungjawab atas data-data di ruangan untuk keberhasilan akreditasi rumah sakit, mengharapkan reward atas beban lebih, emosi karena administrasi dan merasa puas bisa membantu. Disimpulkan bahwa perawat merasa kegiatan administrasi keuangan pasien selama dirawat di ruangan merupakan beban tambahan diluar perannya, selain itu perawat merasa kesulitan menyelesaikannya karena harus membagi waktu dengan perannya sehingga merasa perlu adanya tenaga khusus yang menangani hal tersebut.
\end{abstract}

Kata Kunci: Administration, Perawat, Keuangan, Bangsal and Kesehatan.

\begin{abstract}
The hospital is a place for general health services, but also includes other services that can satisfy all hospital users. Hospital employees as service providers must get satisfaction in their activities. So far, nurses do not only provide nursing care to patients but also other tasks assigned by the institution.

Nurses in their roles in health services are not only as providers of nursing care but also as advocates, educators, collaborators, coordinators, counselors and researchers, and there is health care facilities also require nurses to complete financial administration while the patient is being treated in the room. The implementation of financial administration is not easy except by professionals who have received special education about financial administration and this becomes a burden for nurses. The purpose of this qualitative research is to reveal the nurse's response to the task of financial administration in the treatment room. In-depth interviews were conducted on
\end{abstract}


nurses at hospital to collect data and listen to nurses' thoughts about their experiences in managing financial administration. After going through data analysis and discussions with several qualitative researchers as well as clarification with several nurses, there were 6 (six) themes, namely; stated that he did not have a basic administrative knowledge, felt responsible for the duties of the room including financial administration, felt responsible for the data in the room for the success of hospital accreditation, expected rewards for the extra burden, was emotional because of administration and was satisfied to be able to help. It was concluded that nurses feel the financial administration activities of patients while being treated in the room are an additional burden outside of activities according to their roles, in addition to the difficulty of completing because they have to the provision of nursing care so that they feel the need for special personnel to handle this.

Key word: Administration, Nursing, Financial, Ward and Health

Pendahuluan

Sistem informasi administratif manajemen rumah sakit mengelola semua administrasi data di rumah sakit, salah satunya menyelesaikan masalah dalam billing/pembayaran. Administrasi keuangan di rumah sakit menyelesaikan segala data tentang keuangan rumah sakit termasuk keuangan dalam ruangan. Persatuan Rumah Sakit Indonesia pada tahun 2018 menyampaikan bahwa tata kelola keuangan dan akuntansi rumah sakit masih sangat beragam dengan implementasi administrasi yang menggunakan beberapa standar serta penatalaksananya belum mendapat perhatian utama oleh manajemen rumah sakit, khusunya ketersediaan sistem informasi manajemen keuangan dan akuntansi belum mengikuti standar baku sesuai tuntutan perkembangan ilmu pengetahuan dan teknologi serta perundangan yang berlaku. Dari Komisi Akreditasi Rumah sakit pada BAB 1 Askes ke pelayanan di standar APK 1.2 disebutkan bahwa penjelasan yang meliputi informasi tentang perkiraan biaya kepada pasien dan keluarganya dilakukan khususnya oleh Staff Admisi Rawat Inap dan Rawat Jalan. Serta dalam isian berkas Akreditasi RS dari tingkat pelayanan dasar sampai lengkap sebagai point pertama yang mendapat penilaian adalah Administrasi Manajemen. Berdasarkan Peraturan Menteri Kesehatan Nomor: 147/MENKES/PER///2010 Tanggal: 27 Januari 2010 disebutkan bahwa salah satu syarat dalam izin operasional Rumah Sakit dalam pada Sarana prasarana salah satunya tersedianya ruang administrasi. Dimana dalam administrasi harus tersedia bidang khusus yang mengelola administrasi manajemen yang terdiri dari administrasi umum dan administrasi keuangan. Sebagai institusi publik rumah sakit memberikan pelayanan yang ekstra efektif dan efisien untuk meningkatkan pelayanannya baik dari segi medis maupun non medis. Studi pendahuluan dengan wawancara terhadap beberapa perawat di sebuah rumah sakit di Kabupaten Kediri tentang administrasi keuangan di ruangan, mereka menyatakan merasa ada tambahan tanggung jawab karena harus mengurus masalah keuangan. Administrasi keuangan pasien selama di ruangan menjadi tanggung jawab perawat yang harus diselesaikan khususnya rincian biaya pelayanan selama perawatan. Selain itu mereka tidak pernah mendapatkan pendidikan tentang ilmu administrasi khususnya administrasi keuangan rumah sakit. Administrasi keuangan haruslah dipegang oleh praktisi administrasi yang memahami dan menguasai tujuan dan fungsi dari perangkat administrasi keuangan. Khususnya administrasi keuangan pada pelayanan kesehatan perlu dipahami dan diperhatikan bagaimana dapat dilaksanakan sesuai dengan perkembangan ilmu pengetahuan.

Berdasarkan uraian diatas, ada pekerjaan lain yang harus diselesaikan oleh perawat yaitu sebagai pelaksana administrasi keuangan selain pekerjaan sesuai perannya. Dari studi pendahuluan, perawat sebagai tenaga kesehatan pada layanan keperawatan di rumah sakit juga diharuskan menguasai 
administrasi umum dan menguasai administrasi keuangan. Untuk hal tersebut, peneliti ingin mengetahui pengalaman yang dirasakan perawat atas tugas keadministrasian yang berhubungan dengan keuangan di ruang perawatan. Diharapkan dari data yang didapatkan bisa digunakan sebagai bahan untuk peningkatan mutu pelayanan kesehatan dan memberikan kepuasan pada semua masyarakat di rumah sakit meliputi karyawan, pasien, keluarga dan pengunjung.

\section{Metode}

Penelitian kualitatif ini mengeksplorasi, menemukan, menguraikan dan menjelaskan kualitas subyektifitas perawat selama mengelola administrasi keuangan di ruangan. Partisipan yang terlibat dalam penelitian ini sejumlah 10 (sepuluh) perawat yang sesuai dengan kriteria inklusi yang ditentukan melalui purposive sampling yaitu: 1) Perawat yang telah bekerja lebih dari 10 tahun dan mengerjakan administrasi keuangan di ruang perawatan, 2) Perawat yang mendapat persetujuan dari kepala ruang, 3) Perawat yang bersedia terlibat dalam penelitian, 4) Partisipan bersedia diwawancarai dan direkam selama penelitian dan memberikan persetujuan publikasi hasil penelitian.

Proses rekruitmen partisipan pada penelitian ini dilaksanakan melalui permohonan dan ijin penelitian yang disampaikan ke direktur rumah sakit Amelia Kediri, yang kemudian tersampaikan kepada kepala ruang. Data dikumpulkan setelah partisipan menyetujui mengikuti penelitian dengan wawancara (indept intervew) serta mendengarkan curahan hati para perawat. Wawancara yang dilakukan menggunakan panduan pertanyaan semi-terstruktur. Panduan berisikan tentang pemahaman perawat atas administrasi keuangan yang dikerjakannya di ruang perawatan termasuk harapan, hambatan dan kesulitan yang dirasakannya. Selama wawancara peneliti juga menggunakan catatan lapangan (field note). Setelah data tercukupi selanjutnya peneliti melakukan analisa data menggunakan panduan menurut Linda,
(2011), yaitu Interpretive Phenomenological Analysis (IPA) dengan alur sebagai berikut; membaca transkrip untuk menemukan data yang sejenis atau sepadan, mengumpulkan data sejenis, mencari hubungan antara data yang sama untuk menemukan tema awal, menyimpan tema yang telah didapat dan melanjutkan berpikiran terbuka pada transkrip berikutnya, mencari pola lintas kasus dan mengambil interpretasi.

\section{Hasil}

Data didapatkan dari wawancara mendalam (indept intervew) terhadap sebanyak 10 perawat dari rumah sakit Amelia yang telah bekerja lebih dari 10 tahun di rumah sakit tersebut. Menyatakan merasa terbebani dengan administrasi keuangan sehingga merasa butuh tenaga khusus untuk menyelesaikan administrasi yang ada diruangan. Merujuk pada tujuan penelitian ditemukan hasil sebanyak 6 (enam) tema yaitu: menyatakan tidak mempunyai dasar ilmu keadministrasian, merasa bertanggungjawab atas tugas-tugas diruangan termasuk administrasi keuangan, merasa bertanggungjawab atas data-data di ruangan untuk keberhasilan akreditasi rumah sakit, mengharapkan reward atas beban lebih, emosi karena administrasi dan merasa puas bisa membantu.

Berikut dijelaskan penganalisaan data dari setiap tema yang ditemukan beserta penjelasan dari uraian masing-masing tema dan kategori dengan beberapa kutipan wawancara dari beberapa partisipan.

\section{1) Menyatakan tidak mempunyai dasar ilmu keadministrasian}

Partisipan mengungkapkan bahwa dirinya "Menyatakan tidak mempunyai dasar ilmu keadministrasian" dimana maksud dari tema ini adalah partisipan merasa apa yang menjadi salah satu pekerjaannya diselesaikan tidak dengan ilmu yang didapat selama pendidikan namun hanya berdasarkan pengalaman, ungkapan perawat tersebut seperti berikut: 
“... $\quad \ldots \quad \ldots \quad$ seperti ini hanya berdasarkan pengalaman sehingga yaa nak nuk (bahasa jawa)(tertatihtatih) ........” (P9)

“... $\quad . . \quad$... sepertinya perlu administrasi khusus untuk ruangan menyelesaikan semua urusan di ruangan termasuk billing, datadata sismodar dan mungkin itu perlu untuk meringankan beban ruangan ........ “ $(P 1, P 3, P 5)$

... ... ..., belum nanti hitung billingbilling lainnya menjadi kerjaan kita ......." (P1, P2, P7, P5).

“... ... ... menginput biling itu kalau menurut saya...yaa seharusnya jangan kita (perawat) karena kita punya kompetensi sendiri dan punya kewajiban sendiri, tupoksi sendiri yang memang harus dipenuhi dalam rekam medis ... ... ... (P2, P5)

\section{2) Bertanggungjawab atas tugas-tugas diruangan termasuk administrasi keuangan}

Partisipan mengungkapkan bahwa dirinya "merasa bertanggungjawab atas semua tugas diruangan termasuk administrasi keuangan" dimana maksud dari tema ini adalah partisipan merasa bahwa dirinya harus menyelesaikan semua tugas yang ada di ruangan termasuk dalam administrasi keuangan, ungkapan partisipan seperti berikut:

$\begin{array}{llllll} & . & \ldots & \ldots & \ldots & \text { seperti ini hanya }\end{array}$ berdasarkan pengalaman sehingga yaa nak nuk (bahasa jawa)(tertatihtatih) ........."

“ $\quad$.. $\quad \ldots \quad \ldots \quad$.. jadi kita buat tanggungjawab yang sama, ... ...... ruangan akan berusaha untuk menyelesaikannya, ... ...... (P9) “... ... ... untuk billing harus diselesaikan saat visite dokter selesai, semua wajib bisa. Dan ini menjadi tanggung jawab seтиa petugas ruangan untuk urusan administrasi walaupun itu merupakan bukan kewajiban kita untuk menyelesaikannya ... $\ldots . .$. (P4)

Rasa tanggung jawab dan dedikasi perawat terhadap institusi menuntut untuk menyelesaikan permasalahan yang ada di tempat kerjanya untuk memberikan pelayanan sebaiknya, walaupun itu harus menyebabkan adanya tambahan beban pada perawat.

3) Bertanggungjawab atas keberhasilan akreditasi Rumah Sakit

Partisipan mengungkapkan bahwa dirinya "Bertanggungjawab atas keberhasilan akreditasi Rumah Sakit" dimana maksud dari tema ini adalah partisipan merasa bahwa administrasi dan atau kelengkapan data untuk akreditasi salah satu tanggungjawab yang harus disiapkan, kutipan dari partisipan seperti berikut:

“.... ..... apalagi dengan persiapan akreditasi sekarang jumlah tenaga dibanding dengan jumlah pasien (P7) (mengisyaratkan dengan tangah bahwa jumlah perawat kurang) ........."

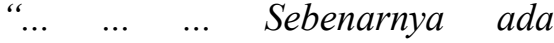
penanggung jawab data tapi ya itu tadi tidak jalan. Apalagi kalau persiapan akreditasi waahh ... ... ... (secara kompak tambah wajah yang mengisyaratkan semakin terbebani).(P2,P4, P5, P8, P3, P1, ) “... ... ... Apalagi sekarang untuk akreditasi berkas rekam medis kita berlomba-lomba untuk menyelesaikan karena sangat memakan waktu sekali. Sehingga sebenarnya untuk urusan administrasi secara umum gak nyandak... (seperti billing, indikator mutu dan lain-lain) P5, P2, P3, P1). ........." 
Akreditasi merupakan hal yang harus didapatkan oleh isntitusi layanan umum sebagai bukti legal status dan kemampuan institusi dalam memberikan layanan pada masyarakat. Untuk itu rumah sakit berupaya untuk mendapatkan pengakuan secara hukum. Sebagai bagian dari sebuah institusi, perawat merasa rumah sakit tempat bekerja harus mendapatkan pengakuan tersebut, sehingga keberhasilan akreditasi rumah sakit juga merupakan tanggungjawabnya untuk mendapatkan hasil yang terbaik.

\section{4) Mengharapkan reward atas beban lebih}

Partisipan mengungkapkan bahwa dirinya "Mengharapkan reward atas beban lebih dari administrasi yang telah dikerjakan", seperti yang disampaikan oleh perawat pada kutipan berikut:

“... ... ... terus terang dari segi reward ... kita itu semua sama .. jadi walaupun beban berat atau ringan itu sudah ditentukan rumah sakit sejak lama... ......" (P2)

... ... ... Hmmmm selama ini tidak ada reward dari pimpinan selain itu, seperti rekreasi tapi yaa bersama-sama semua karyawan ... ... (P4)

Perawat sebagai pekerja di rumah sakit merupakan suatu kewajaran bila apa yang dikerjakannya mendapatkan imbalan yang sesuai. Perawat merasa administrasi keuangan bukanlah merupakan tanggungjawabnya untuk diselesaikan. Kegiatan mengelola masalah keuangan di ruangan tidaklah mudah, dimana perawat merinci pembiayaan atas layanan yang diberikan pada pasien di ruangan dan untuk menyelesaikannya perlu waktu dan pikiran selain harus menyelesaikan asuhan keperawatan dan peran lainnya. Bertambahnya pekerjaan harus sebanding dengan imbalan yang diterima, sehingga perawat merasa bahwa beban administrasi yang telah dikerjakan berharap mendapatkan reward yang sesuai.

\section{5) Emosi karena administrasi}

Partisipan mengungkapkan bahwa dirinya "Emosi karena administrasi tak terselesaikan" dimana maksud dari tema ini adalah partisipan stress dan terkadang emosi bila pekerjaan di ruangan tidak selesai termasuk administrasi keuangan ruangan yang menurutnya bukan tanggungjawabnya. Hal tersebut disampaikan seperti berikut:

$$
\begin{aligned}
& \text { belum nanti hitung billing-billing } \\
& \text { lainnya menjadi kerjaan kita, } \\
& \text { akhirnya yaa ... gitulah (emosi) ... } \\
& \text {.....” (P1, P2, P7, P5). } \\
& \text { “........ secara psikologis kita jadi } \\
& \text { emosi karena bagian orang lain } \\
& \text { kita bantu, namun menjadi } \\
& \text { kebiasaan sehingga berkas yang } \\
& \text { tidak sampai di poli menjadi } \\
& \text { kesalahan kita ......... "(P6, P5). }
\end{aligned}
$$

\section{6) Puas bisa membantu}

Partisipan mengungkapkan bahwa dirinya "Merasa Puas bisa membantu" dimana maksud dari tema ini adalah partisipan merasa senang bisa membantu orang lain, seperti berikut:

“ ... ... ... Yoo puas sebenarnya bisa bantu, tapi itu lho kalau pas lagi banyak masalah ... untuk urusan administrasi jadi emosi aja bawaannya karena urusan pasien belum selesai sudah harus menyelesaikan urusan administrasi yang se-abrek.... (P9, P4)

“ ... ... ... puas sebenarnya, ketika menyendiri itu (sambil menunjukkan sedang merenung). Puas dengan apa yang dikerjakannya dengan beban seperti itu, iso nulungi kancane nulungi wong liyo (bisa menolong teman menolong orang lain), ... ... ... $(P 7, P 8, P 4)$ 
Tolong menolong dalam segala kegiatan sangatlah baik. Perawat dengan jiwa caring nya merasa kepuasan bisa membantu orang lain, termasuk dalam kegiatan

\section{Pembahasan}

\section{Menyatakan tidak mempunyai dasar ilmu keadministrasian}

Perawat sebagai staff pelaksana telah mempunyai tugas sesuai kompetensinya dalam layanan di rumah sakit, merasa kewalahan dalam hal mengatur data-data mengenai pasien dan perekapan administrasi keuangan (Utami, 2015). Hal tersebut terjadi karena semakin banyaknnya pasien menyebabkan beban kerja yang sesuai tupoksi nya telah bertambah dan ditambah lagi harus menyelesaikan urusan mengelola data-data keuangan sehingga Perlu adanya pelatihan atau tambahan pendidikan lanjut untuk karyawan pelaksana pada administrasi keuangan (Suharyono, U. (2000). Sedangkan pada subjek penelitian adalah perawat yang telah mempunyai tanggung jawab khususnya pada asuhan keperawatan dan tindakan lainnya perannya sesuai dengan pendidikannya, sedangkan untuk pelaksanaan pengelolaan administrasi keuangan hanyalah didapat dari pengalaman karena kewajiban yang harus diselesaikan di ruangan.

\section{Bertanggungjawab atas tugas-tugas diruangan termasuk administrasi keuangan}

Ruang perawatan sebagai tempat memberikan layanan kesehatan khususnya oleh perawat untuk perawatan pasien berada dibawah tanggungjawab kepala ruang dan seluruh staff yang ada di ruangan atas semua kegiatan di dalamnya. Di ruangan tersebut perawat juga bertanggungjawab terhadap administrasi pemenuhan hak pasien (Rahma Yetti, 2019). Permasalahan yang ada di ruangan harus terselesaikan untuk memberikan kenyamanan bagi semuanya yang berhubungan dengan ruangan tersebut.
Administrasi keuangan ruangan merupakan masalah tersendiri bagi perawat karena mereka tidak mempunyai pendidikan khusus keadministrasian dan harus terselesaikan.

\section{Bertanggungjawab atas keberhasilan akreditasi Rumah Sakit}

Akreditasi rumah sakit menuntut kelengkapan data dari seluruh elemen akreditasi, kepala ruang beserta staff bertanggungjawab terhadap pasien di rumah sakit termasuk dalam hal administrasi yang diperlukan oleh pasien (KARS, 2012). Keberhasilan dalam memberikan layanan yang dibuktikan dengan akreditasi merupakan tanggungjawab semua staff di rumah sakit dimulai dari pimpinan sampai staff terbawah. Banyak data yang diperlukan dalam penilaian akreditasi, salah satunya adalah kepuasan pasien. Semua staff berperan sama dalam melaksanakan tugasnya sesuai dengan profesinya masing-masing.

\section{Mengharapkan reward atas beban lebih}

Imbalan jasa memberikan kepuasan dan kebahagiaan bagi pekerja bila sesuai dengan beban kerjanya, seperti dalam penelitian Apolinario (2014) bahwa ada pengaruh positif dan signifikan imbalan dengan kinerja pegawai. Namun menurut perawat yang ada di ruangan, mereka merasa belum mendapatkan imbalan yang sesuai dengan tugas yang telah diselesaikannya yaitu administrasi keuangan yang merupakan keilmuan tersendiri diluar tugas pokok.

\section{Emosi karena administrasi}

Suatu pekerjaan yang menuntut ketrampilan khusus memerlukan pendidikan khusus yang sesuai. Ketidakpahaman alur kerja memberikan ketidakketenangan dalam bekerja, selain itu pekerjaan yang tidak didasari dengan ilmu memadahi akan menjadi tekanan tersendiri bagi pekerja. Tekanan yang ada tersebut dapat membuat emosi karena orang tersebut kesulitan menyelesaikan pekerjaanya. Menurut Sastra (2017), seorang karyawan akan mengalami reaksi emosional 
karena adanya beban kerja yang terlalu berlebihan, hal ini terjadi karena kurangnya kompetensi dalam menyelesaikan masalah yang dihadapi dan memungkinkan akan berdampak tekanan psikis (Arwin dkk, 2019). Kompetensi dalam administrasi keuangan yang kurang dikuasi oleh perawat dapat menyebabkan masalah emosional

\section{Puas bisa membantu}

Terdapat banyak hal yang dapat mempengaruhi kepuasan kerja seseorang. Berdasarkan hasil wawancara awal didapat bahwa salah satu alasan merasa puas dengan pekerjaan yang dijalani saat ini karena bisa membantu teman kerja lain disaat tidak banyak pekerjaan untuk dirinya sendiri. Menurut Putra dan Ruslita (2015), memberikan bantuan bisa membuat rasa bangga akan apa yang telah dilakukan sehingga dapat memberi kepuasan pada diri sendiri. Sudah menjadi hal alamiah manusia, dimana seseorang mempunyai kebutuhan dasar untuk memberi dan meminta pertolongan. Perilaku saling membantu merupakan naluriah manusia sebagai makluk sosial. Hal ini menjadikan kepuasan tersendiri bagi pelaku dapat membantu orang lain, karena dapat meringankan beban orang lain.

\section{Simpulan}

Perawat dalam kegiatannya menyelesaikan administrasi keuangan pasien merasa bahwa hal tersebut merupakan beban tambahan diluar perannya sebagai perawat dan kesulitan karena tidak mempunyai latarbelakang ilmu keadministrasian keuangan sehingga harus bisa membagi waktu dengan perannya. Perawat merasa perlu adanya tenaga khusus administrasi yang menangani hal tersebut. Namun dalam kesehariannya perawat merasa senang bisa menyelesaikan urusan tersebut walaupun kadang merasa emosi bila perasnya sendiri sebagai perawat belum terselesaikan dan harus menyelesaikan masalah keadministrasian.

\section{Saran}

Menghadapi tuntutan kerja dan profesionalitas pekerjaan dalam menyelesaikan masalah di rumah sakit khususnya administrasi diperlukan tenaga khusus dalam menyelesaikannya sesuai peran dan fungsinya. Perlu penelitian lebih lanjut untuk mengetahui kejelasan peran dan fungsi adanya tenaga administrasi khusus di ruangan yang menyelesaikan urusan keadministrasian dengan peran dan fungsi perawat sesuai dengan kompetensi masing-masing.

\section{Ucapan terima kasih}

Penulis sampaikan terima kasih kepada Direktur dan seluruh staff Rumah Sakit Amelia Pare Kediri yang berada di Jln. Pahlawan 25 A Pare Kediri, khususya perawat yang telah bersedia menjadi partisipan dan memberi kesempatan peneliti melakukan pengumpulan data dalam penelitian ini. Ucapan terimakasih juga disampaikan kepada Lembaga Penelitian dan Pengabdian Masyarakat (LPPM) Stikes Pamenang Kediri yang telah menyediakan dana untuk penelitian ini.

\section{Daftar Pustaka}

https://persi.or.id/buku-direktori-rumah-sakitseluruh-indonesia-edisi-2018/ diakses tanggal 08 Mei 2021.

PERMENKES Nomor 012 Tahun 2012, tentang Akreditasi Rumah Sakit.

Linda, S. (2011). Phenomenology for Therapists. Researching the lived World. Publiser Wiley-Blackwell. 1st Edition, ISBN-13: 978-0470666456

Utami, L. A. (2015). Sistem Informasi Administrasi Pasien pada Klinik Keluarga Depok. Konferensi Nasional Ilmu Pengetahuan Dan Teknologi (KNIT).

Suharyono, U. (2000). Analisis hubungan karakteristik karyawan di Bagian Administrasi Keuangan dan Umum dengan persepsinya terhadap pekerjaan di RS. Setia Mitra.

Rahma Yetti, Z. (2019). Tanggungjawab Perawat Terhadap Pemenuhan Hak-Hak Pasien Di Ruang Rawat Inap Rsud Solok Selatan. Jurnal Program Pascasarjana, 15(4). 
Sakit, K. A. R. (2012). Instrumen akreditasi rumah sakit standar akreditasi versi 2012. Jakarta: KARS.

Komisi Akreditasi Rumah Sakit (2012), Instrumen Akreditasi Rumah Sakit, Standar Akreditasi Versi 2012 Edisi-1, Tahun 2012 Jakarta. Apolinario. (2014) Pengaruh Imbalan, Motivasi Dan Kepuasan Kerja Terhadap Kinerja Pegawai Kejaksaan Agung Dan Kejaksaan Distrik Dili ISSN : 2337-3067 E-Jurnal Ekonomi Dan Bisnis Universitas Udayana 3.10 (2014) :599-613

Sastra B A (2017), Pengaruh Kompetensi Karyawan Dan Beban Kerja Terhadap Kinerja Karyawan Bank Danamon Cabang Tuanku Tambusai Pekanbaru, JOM Fekon Vol.4 No.1 (Februari) 2017, hal 590 - 600.

Arwin, A., Ciamas, E. S., Siahaan, R. F. B., Vincent, W., \& Rudy, R. (2019, February). Analisis Stress Kerja Pada PT. Gunung Permata Valasindo Medan. In Seminar Nasional Teknologi Komputer \& Sains (SAINTEKS) (Vol. 1, No. 1).

Putra. IDGU dan Ruslita IM ( 2015), Hubungan Antara Perilaku Menolong Dengan Konsep Diri Pada Remaja Akhir Yang Menjadi Anggota Tim Bantuan Medis Janar Duta Fakultas Kedokteran Universitas Udayana, Jurnal Psikologi Udayana 2015, Vol. 2, No. 2, 198-205 Program Studi Psikologi, Fakultas Psikologi, Universitas Udayana ISSN: 23545607198 